\title{
Genetic Background in Patients with Acute Myocardial Infarction
}

\author{
Shuichi AoKI, MD, Shuji MukaE, MD, Seiji ITOH, MD, \\ Ryuji SATO, MT, Kazuaki NishIO, MD, Hiroaki UEDA, MD, \\ Toshiki IwATA, MD, and Takashi KATAGIRI, MD
}

\section{SUMMARY}

The renin-angiotensin system is believed to play important roles in the development of acute myocardial infarction, and gene polymorphisms may also be involved. To investigate the genetic background in patients with acute myocardial infarction, we performed a case control study in a Japanese population.

The study included 150 patients with acute myocardial infarction and 150 healthy, age- and sex-matched controls. We examined polymorphisms of angiotensin II type 1 receptor $(1166 \mathrm{~A} / \mathrm{C})$, type 2 receptor $(3123 \mathrm{C} / \mathrm{A})$, and bradykinin $\mathrm{B} 2$ receptor $(-58 \mathrm{~T} /$ C) in these subjects.

The allelic frequencies of angiotensin II type 1 receptor $\mathrm{C}$ and angiotensin II type 2 receptor A were significantly higher in the acute myocardial infarction subjects than in the control subjects, and this tendency was more significant in the younger patients. The combined ratios of angiotensin II type 1 receptor C and type 2 receptor A alleles in patients under 64 years old were significantly higher than in their older counterparts. However the total numbers of conventional coronary risk factors (hypertension, hypercholesterolemia, diabetes mellitus, and smoking) in individual subjects were not significantly different between younger and older patients.

These polymorphisms were found to be involved in the development of acute myocardial infarction, particularly in the younger patients, and it was concluded that the incidence of acute myocardial infarction might be reduced by management from the genotypes. (Jpn Heart J 2001; 42: 15-28)

Key words: Renin-angiotensin system, Polymorphism, Acute myocardial infarction, Coronary risk factor

HYPERTENSION, hypercholesterolemia, diabetes mellitus, and smoking have been identified as risk factors for coronary heart disease by many epidemiological studies. However, coronary heart disease is thought to result from the interaction of multiple environmental and genetic factors, one of which may be the reninangiotensin system. ${ }^{1,2)}$ It has been suggested that the components of the renin-

From Third Department of Internal Medicine, Showa University School of Medicine, Tokyo, Japan.

Address for correspondence: Shuji Mukae, MD, Third Department of Internal Medicine, Showa University School of Medicine 1-5-8 Hatanodai, Shinagawa-ku, Tokyo 142-8666, Japan.

Received for publication June 9, 2000.

Revised and accepted September 16, 2000. 
angiotensin system play a major role in the pathogenesis of a wide variety of cardiovascular diseases. ${ }^{3)}$

The major biologically active product of the renin-angiotensin system is angiotensin II, a peptide with multiple functions. In adult humans, the effects of angiotensin II are mainly mediated by the angiotensin II type 1 receptor, a G-protein-coupled receptor expressed by many cell types. On the other hand, human angiotensin II type 2 receptor genes have also recently been cloned and mapped to the X-chromosome. ${ }^{4,5)}$ The expression of angiotensin II type 2 receptor is abundant in fetal tissues, but scanty in adult tissues. ${ }^{6,7)}$ This receptor is also re-expressed in myocardial infarction, cardiac hypertrophy, vascular injury, and skin wounds. ${ }^{8-10)}$ These findings suggest that the angiotensin II type 2 receptor is activated in various pathophysiological states and may play important roles in the pathogenesis of these states. Furthermore, angiotensin II type 2 receptor works cardioprotectively against type 1 receptor. ${ }^{11,12}$ Given the known physiological roles of these receptors, the angiotensin II type 1 and type 2 receptor genes are suspected as susceptibility factors for coronary heart disease.

Genetic variation has also been described in the components of the renin-angiotensin system. ${ }^{13,14)}$ These genetic variations contribute to individual heterogeneity in the status of the renin-angiotensin system and thereby modify the relative role of the renin-angiotensin system in cardiovascular disease. Recently, investigators have described two genetic susceptibility factors for myocardial infarction that act synergistically on components of the renin-angiotensin system, i.e., the insertion/deletion (I / D) polymorphism of the ACE gene ${ }^{13}$ and the adenine (A) / cytosine (C) 1166 transversion of the angiotensin II type 1 receptor gene. ${ }^{14)}$

On the other hand, bradykinin in the kallikreins-kinin system, promotes all the major signs of inflammation such as hyperemia, leakage of plasma proteins, and pain. ${ }^{15-17)}$ Bradykinin also exerts a cardioprotective effect on the myocardium. Kinins act mainly as local hormones by activating specific receptors known as B1 and B2 receptors, the latter of which mediates most of the inflammatory and cardiovascular effects. ${ }^{17-19)}$ Human bradykinin receptor is a cell-surface, G-protein-coupled receptor of the seven-transmembrane-domained superfamily. ${ }^{15)}$ The human B2 bradykinin receptor cDNA was cloned by Hess, et al. ${ }^{20)}$ and subsequent studies of the genomic structure have shown the four polymorphisms. ${ }^{21-23)}$ The bradykinin B2 receptor gene has been implicated as one of the candidate genes involved in the complex genetic underpinnings of essential hypertension and cardiovascular diseases. We already reported that the bradykinin B2 receptor -58 thymine (T) / cytosine (C) polymorphism was 
associated with the occurrence of essential hypertension in a Japanese population, ${ }^{24)}$ and Braun supports our data by reporting that the luciferase promoter assay of $-58 \mathrm{C}$ in the bradykinin $\mathrm{B} 2$ receptor was lower than that of $-58 \mathrm{~T}{ }^{23)}$ Accordingly, we concluded that the transcriptional activity of the receptor promoter might be involved in the appearance of essential hypertension. However, there have been no other papers addressing associations between the bradykinin B2 receptor polymorphisms and diseases, so further study will be needed to clarify the role of this polymorphism.

In this study, we investigated how polymorphisms of the angiotensin II type 1 receptor, angiotensin II type 2 receptor, and bradykinin B2 receptor contribute to acute myocardial infarction (AMI) in a Japanese population. There have been many papers published on the ACE I/D polymorphism, ${ }^{13,25)}$ as well as several others on the angiotensin II type 1 receptor A / C polymorphism in European and American populations with coronary heart diseases. ${ }^{14)}$ In these studies, the physiological role of angiotensin II type 1 receptor implicates the angiotensin II type 1 gene as a candidate gene risk factor for myocardial infarction that may interact with the ACE I / D polymorphism. But other papers completely discount the relation between the angiotensin II type 1 receptor polymorphism and AMI. ${ }^{26,27)}$ Hence, there is no established theory about the role of the angiotensin II type 1 receptor polymorphism in European and American populations. Furthermore, the mechanism of the angiotensin II type 2 receptor remains especially obscure, and few papers have described the angiotensin II type 2 receptor polymorphism. Several similar studies have been conducted on the ACE I / D polymorphism in Japanese populations, ${ }^{28,29)}$ but few have described the angiotensin II type 1, type 2 receptors, or bradykinin B2 receptor polymorphisms in AMI subjects in Japan. ${ }^{30}$ )

We investigated our hypothesis in a case control study comparing patients who survived myocardial infarction with appropriate controls recruited from a different Japanese population.

\section{METHODS}

Study population: Genetic polymorphisms were examined in 150 patients (102 men and 48 women) with AMI who underwent coronary angiography at Showa University Hospital, Tokyo, Japan in 1997-1999. AMI was diagnosed by clinical evidence of cardiac attack, electrocardiogram criteria, and serum cardiac enzyme concentrations. The clinical characteristics of the patients are shown in Table I. We defined conventional coronary risk factors as hypertension, hypercholesterolemia, diabetes mellitus, and 
Table I. Clinical Characteristics of Control Subjects and AMI Subjects

\begin{tabular}{llll}
\hline & No. (male / female) & Age (years) & $p$ value \\
\hline Control subjects & $150(102 / 48)$ & $62 \pm 10$ & NS \\
AMI subjects & $150(102 / 48)$ & $64 \pm 8$ & \\
$64<$ AMI subjects & $78(53 / 25)$ & $60 \pm 7$ & \\
$64 \geqq$ AMI subjects & $72(49 / 23)$ & $71 \pm 5$ & \\
\hline
\end{tabular}

Age is expressed as mean \pm standard deviations, and comparison was performed by ANOVA.

smoking, and the presence of these risk factors was determined from medical records diagnosed before admission due to AMI. The AMI was complicated with hypertension (46\%), hypercholesterolemia (31\%), diabetes mellitus (32\%) and smoking (59\%) in these patients. A smoking habit was defined as a daily intake of 10 or more cigarettes. Diagnosis of diabetes mellitus was performed according to the World Health Organization criteria. ${ }^{31)}$

Normal healthy subjects $(n=150)$ on routine visits to medical centers in Tokyo were recruited as controls (102 men and 48 women) from the vital statistics of the Japanese Ministry of Welfare. Their status was confirmed by physical and laboratory examinations, including electrocardiography, and a history free from cardiovascular disease. All of their clinical data were within normal limits, including blood pressure, total cholesterol, and plasma glucose. All subjects gave informed consent to participate in the study, and the study was approved by the Showa University Ethics Committee. Blood samples were collected from the peripheral vein and stored in vacutainer tubes containing EDTA anticoagulant, and then genomic DNA was prepared from the white blood cells.

Determination of Genotypes: (1) Angiotensin II type 1 receptor 1166 adenine / cytosine polymorphism; The detection of the angiotensin II type 1 receptor $1166 \mathrm{~A} / \mathrm{C}$ polymorphism was determined by polymerase chain reaction $(\mathrm{PCR})$ and restriction isotyping using the restriction endonuclease Dde 1 and primers previously described by Doria, et al. ${ }^{32)}$ Alleles were visualized on $2 \%$ agarose gels stained with ethidium bromide. PCR was performed to amplify a fragment encompassing the A / C polymorphic site at the 1166 nucleotide position in the 3' untranslated region of the human angiotensin II type 1 receptor gene. The design of the primers was as follows: sense, 5'-ATAATGTAAGCTCATCCACC-3'; antisense, 5'-GAGATTGCATTTCTGTCAGT-3'. The $30 \mu \mathrm{l}$ reaction volume contained $100 \mathrm{ng}$ genomic DNA, $10 \mathrm{pmol}$ of each primer, $250 \mu \mathrm{mol} / l \mathrm{dNTP}, 1.0 \mathrm{mmol} / l$ 
$\mathrm{MgCl} 2,50 \mathrm{mmol} / l \mathrm{KCl}, 10 \mathrm{mmol} / l$ Tris- $\mathrm{HCl}$ at $\mathrm{pH} 8.3$, and 0.5 units of Taq polymerase. Amplification was carried out using a Thermal Cycler (PERKIN ELMER 2400). Cycle conditions for PCR were heating for 5 min at $94^{\circ} \mathrm{C}, 40$ cycles of $30 \mathrm{sec}$ at $94^{\circ} \mathrm{C}, 45 \mathrm{sec}$ at $55^{\circ} \mathrm{C}$, and $45 \mathrm{sec}$ at $72^{\circ} \mathrm{C}$ as the main reaction, followed by a final extension at $72^{\circ} \mathrm{C}$ for 10 min. After confirming that the PCR products showed exact amplification, they were digested with Dde I for 3 hours at $37^{\circ} \mathrm{C}$. The digested products were visualized on $2 \%$ agarose gel by ethidium bromide staining.

(2) Angiotensin II type 2 receptor cytosine / adenine polymorphism; We designed the following primers: sense, 5'-GGATTCAGATTTCTCTTTGAA-3'; antisense, 5' GCATAGGAGTATGATTTAATC-3'. PCR was performed under the same conditions used for the angiotensin II type 1 receptor gene polymorphism, with the exception of the annealing temperature, which was set at $53^{\circ} \mathrm{C}$. After confirming DNA amplification, $10 \mu \mathrm{l}$ of the PCR product was digested with 12 units of Alu I for 3 hours at $37^{\circ} \mathrm{C}$, then electrophoresed on $2 \%$ agarose gel with ethidium bromide staining. ${ }^{30,33)}$

(3) Bradykinin B2 receptor -58 thymine / cytosine polymorphism; The primers for PCR amplification were sense, 5'- GCAGAGCTCAGCTGGAGGAG-3', located in the promoter, and antisense 5'-CCTCCTCGGAGCCCAGAAG-3', located in the promoter/exon 1. Primers were designed from the bradykinin B2 receptor gene reported by Kammerer, et $a l .{ }^{22)}$ The total reaction volume was $100 \mu \mathrm{l}$, in a mixture containing $1 \mu \mathrm{g}$ of genomic DNA, $50 \mathrm{ng}$ of each primer, $200 \mu \mathrm{mol}$ of each dNTP, 1.5 $\mathrm{mmol} / l$ of $\mathrm{MgCl}$, and 0.5 units of Taq DNA polymerase. Cycle conditions for PCR were an initial step of $5 \mathrm{~min}$ at $94^{\circ} \mathrm{C}$, followed by 30 cycles of $1 \mathrm{~min}$ at $94^{\circ} \mathrm{C}, 30 \mathrm{~s}$ at $58^{\circ} \mathrm{C}$, and $30 \mathrm{~s}$ at $72^{\circ} \mathrm{C}$, followed by a final extension of $5 \mathrm{~min}$ at $72^{\circ} \mathrm{C}$. PCR products were subjected to single-strand conformation polymorphism (SSCP) electrophoresis. A $10 \mu l$ aliquot of the PCR product was diluted with $30 \mu l$ formamide, denatured at $95^{\circ} \mathrm{C}$ for $10 \mathrm{~min}$, and subjected to SSCP analysis in a $20 \%$ polyacrylamide $(2 \times \mathrm{TBE})$ gel. Electrophoresis was carried out in $2 \times \mathrm{TBE}$ buffer at $24^{\circ} \mathrm{C}$ at $180 \mathrm{~V}$ for 20 hours, and the gels were then silver-stained. SSCP analysis of 300 unrelated Japanese subjects was performed in the same way. Several samples representative of each genotype detected by SSCP were sequenced by fluorescent cycle sequencing to confirm the thymine (T) or cytosine (C) at nucleotide position -58 upstream of the putative transcription start site. 


\section{Statistical ANALYSIS}

Differences in clinical characteristics between the subjects were examined by ANOVA for parametric data. Differences in the genotype and allelic frequencies between the groups were analyzed using the $\chi^{2}$ test, and Fisher's test was used for sets with small numbers. A probability of less than $p<0.05$ was taken to be significant. In the multivariate regression analysis, the 3 polymorphisms and the presence of conventional coronary risk factors (hypertension, hypercholesterolemia, diabetes mellitus; absence $=0$, presence $=1$ ) were considered independent variables.

\section{RESULTS}

In samples obtained from 300 unrelated Japanese individuals, PCRrestriction fragment length polymorphism (PCR-RFLP) electrophoresis in a $2 \%$ agarose gel disclosed two sets of three genotypes for the angiotensin II type 1 and type 2 receptor gene polymorphisms, and PCR-SSCP electrophoresis in a $20 \%$ polyacrylamide gel disclosed one set of three genotypes for the bradykinin B2 receptor gene polymorphism. Figure 1 shows $\mathrm{AA}, \mathrm{CC}$, and $\mathrm{AC}$ genotypes of the angiotensin II type 1 receptor 1166 polymorphism, and $\mathrm{CC}, \mathrm{AA}$, and $\mathrm{CA}$ genotypes of the angiotensin II type 2 receptor 3123 polymorphism.

Figure 2 also shows genotypes for the bradykinin B2 receptor gene -58 thymine / cytosine polymorphism, and DNA sequencing showed a thymine $(\mathrm{T})$ or cytosine $(\mathrm{C})$ at nucleotide position -58 upstream of the
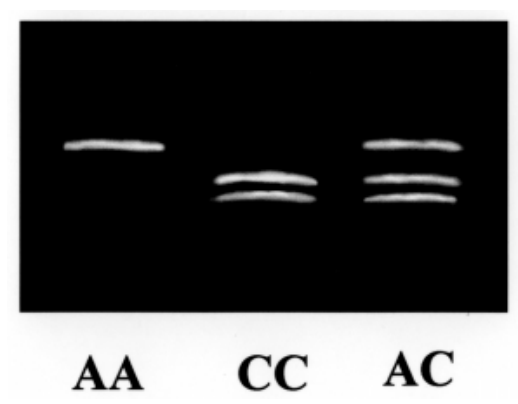
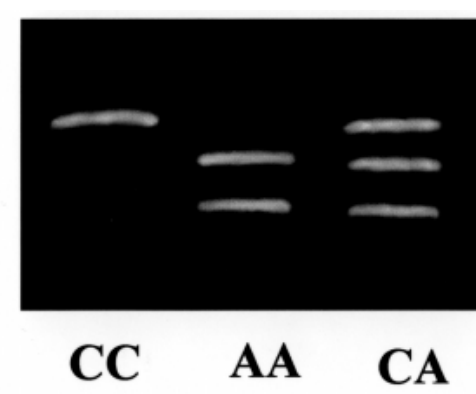

Figure 1. Agarose gel electrophoresis of polymerase chain reaction products to determine Angiotensin II type 1 receptor A / C genotypes (digestion by Dde 1) and Angiotensin II type 2 receptor C / A genotypes (digestion by Alu I). Angiotensin II type 1 receptor (1166 A / C), Angiotensin II type 2 receptor $(3123 \mathrm{C} / \mathrm{A})$. 


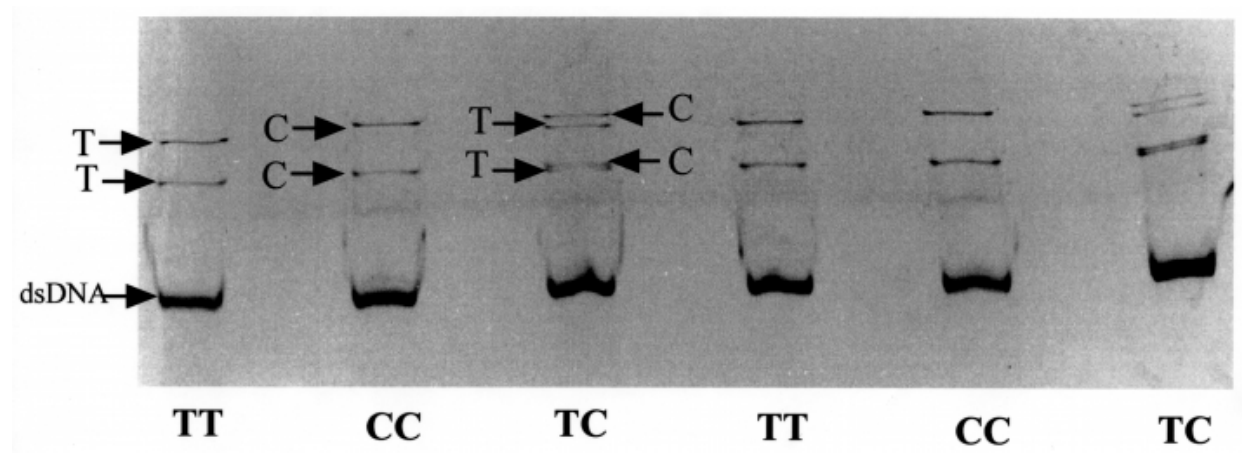

Figure 2. Single-strand conformation polymorphism (SSCP) analysis for-58T / C of human Bradykinin B2 receptor gene. TT: thymine-thymine CT: cytosine-thymine CC: cytosine-cytosine. Upper and third bands from the top are cytosine, second and fourth bands from the top are thymine.

Table II. Distributions of Genotypes and Allelic Frequencies for Human Angiotensin II Type 1 Receptor, Type 2 Receptor and Bradykinin, B2 Receptor Gene Polymorphisms in Control Subjects and AMI Subjects

\begin{tabular}{lllllllll}
\hline & & Genotype & & $\chi^{2}$ test & \multicolumn{2}{c}{ Allele } & \multicolumn{2}{c}{ Odds ratio } \\
\hline Angiotensin II type 1 receptor & AA & AC & CC & & A & C & \\
Control subjects $(n=150)$ & $141(94 \%)$ & $8(5.3 \%)$ & $1(0.7 \%)$ & $\chi^{2}=15.426$ & 0.97 & 0.03 & $3.22(95 \%$ CI 1.55-6.72) \\
AMI subjects $(n=150)$ & $120(80 \%)$ & $30(20 \%)$ & $0(0 \%)$ & $p^{* *}=0.0004$ & 0.9 & 0.1 & $p^{* *=0.001}$ \\
\hline Angiotensin II type 2 receptor & & & & & C & A & \\
Control subjects $(n=150)$ & & & & & 0.83 & 0.17 & $2.43(95 \%$ CI 1.65-3.58) \\
AMI subjects $(n=150)$ & & & & & 0.67 & 0.33 & $p^{* *=0.0001}$ \\
\hline Bradykinin B2 receptor & TT & TC & CC & & T & C & \\
Control subjects $(n=150)$ & $38(25.3 \%)$ & $86(57.4 \%)$ & $26(17.3 \%)$ & $\chi^{2}=0.769$ & 0.54 & 0.46 & $1.11(95 \%$ CI 0.81-1.53) \\
AMI subjects $(n=150)$ & $36(24.0 \%)$ & $82(54.7 \%)$ & $32(21.3 \%)$ & $p=0.680$ & 0.51 & 0.49 & $p=0.513$ \\
\hline
\end{tabular}

putative transcription start site for the bradykinin B2 receptor gene polymorphism.

Table II shows the distributions of the genotypes and the allelic frequencies of the gene polymorphisms of angiotensin II type 1 receptor, angiotensin II type 2 receptor, and bradykinin B2 receptor in control subjects and AMI subjects. The genotypes and allelic frequenceis were in Hardy-Weinberg equilibrium. In the distributions of the genotypes and the allelic frequencies of the angiotensin II type 1 receptor gene, significantly higher incidences of the AC genotype $\left(\chi^{2}=15.426, p=0.0004\right)$ and $\mathrm{C}$ 
allele (odds ratio 3.22 (95\% confidence interval $1.55-6.72, p=0.001)$ ) were seen in AMI subjects compared to controls.

Table II also shows the allelic frequencies of the angiotensin II type 2 receptor gene polymorphism. The angiotensin II type 2 receptor gene has been mapped to the X-chromosome, so here we only show the allelic frequencies. A significantly higher incidence of the A allele was seen in AMI subjects compared to controls, and the odds ratio was estimated as 2.43 (95\% confidence interval $1.65-3.58, p=0.0001)$.

In marked contrast, the distributions of the genotypes and the allelic frequencies of the bradykinin B2 receptor gene were not significantly different between the AMI subjects and controls.

Incidentally, over the past decade, 916 AMI patients, aged an average of 64 years old were admitted to the coronary care unit at Showa University Hospital. Therefore, we divided the AMI subjects into two subgroups, those younger than 64 years old and those older, and we investigated the distributions of the genotypes and allelic frequencies of the genetic polymorphisms within these two groups.

Table III shows the distributions of the genotypes and allelic frequencies of the angiotensin II type 1 receptor, type 2 receptor, and bradykinin B2 receptor genes in AMI subjects less than 64 years old and over 64 years old. In the distributions of the genotypes and the allelic frequencies of the angiotensin II type 1 receptor gene polymorphism, significantly higher incidences of the AC genotype and $\mathrm{C}$ allele were seen in the younger group (allele, odds ratio 2.33 (95\% confidence interval 1.03-5.28,

Table III. Distributions of Genotypes and Allelic Frequencies for Human Angiotensin II Type 1 Receptor, Type 2 Receptor and Bradykinin B2 Receptor Gene Polymorphisms in AMI Subjects Less than 64 Years Old and over 64 Years Old

\begin{tabular}{|c|c|c|c|c|c|c|c|}
\hline \multirow[b]{2}{*}{ Angiotensin II type 1 receptor } & \multirow[b]{2}{*}{$\mathrm{AA}$} & \multicolumn{2}{|l|}{ Genotype } & \multirow[t]{2}{*}{$\chi^{2}$ test } & \multicolumn{2}{|c|}{ Allele } & \multirow[t]{2}{*}{ Odds ratio } \\
\hline & & $\mathrm{AC}$ & $\mathrm{CC}$ & & A & $\mathrm{C}$ & \\
\hline $64<$ AMI subjects $(n=78)$ & $57(73.1 \%)$ & $21(26.9 \%)$ & $0(0 \%)$ & $\chi^{2}=4.868$ & 0.87 & 0.13 & $2.33(95 \%$ CI $1.03-5.28)$ \\
\hline $64 \geq$ AMI subjects $(n=72)$ & $63(87.5 \%)$ & $9(12.5 \%)$ & $0(0 \%)$ & $p^{*}=0.027$ & 0.94 & 0.06 & $p^{*}=0.038$ \\
\hline Angiotensin II type 2 receptor & & & & & $\mathrm{C}$ & A & \\
\hline $64<$ AMI subjects $(n=78)$ & & & & & 0.6 & 0.4 & $1.91(95 \%$ CI $1.17-3.12)$ \\
\hline $64 \geq$ AMI subjects $(n=72)$ & & & & & 0.74 & 0.26 & $p^{*}=0.010$ \\
\hline Bradykinin B2 receptor & TT & $\mathrm{TC}$ & $\mathrm{CC}$ & & $\mathrm{T}$ & $\mathrm{C}$ & \\
\hline $64<$ AMI subjects $(n=78)$ & $17(21.8 \%)$ & $42(53.8 \%)$ & $19(24.4 \%)$ & $\chi^{2}=1.047$ & 0.49 & 0.51 & 1.24 (95\% CI 0.79-1.96) \\
\hline $64 \geqq$ AMI subjects $(n=72)$ & $19(26.3 \%)$ & $40(55.6 \%)$ & $13(18.1 \%)$ & $p=0.593$ & 0.54 & 0.46 & $p=0.346$ \\
\hline
\end{tabular}


$p=0.038)$ ). Furthermore, a significantly higher incidence of the A allele in the younger group was also seen in the allelic frequencies of the angiotensin II type 2 receptor gene (odds ratio 1.91 (95\% confidence interval $1.17-3.12, p=0.010)$ ). On the contrary, there were no significant differences within these two groups in the distributions of the genotypes and allelic frequencies of the bradykinin B2 receptor gene, but a higher incidence of the $\mathrm{T}$ allele was seen in the overall population of AMI subjects (Table II) and in the older AMI group (Table III), while a higher incidence of the $\mathrm{C}$ allele was seen in the younger AMI group.

Table IV. Combination Ratios of Angiotensin II Type 1 Receptor C Allele and Angiotensin II Type 2 Receptor A Allele in AMI Subjects less than 64 Years Old and Over 64 Years Old

\begin{tabular}{llll}
\hline Angiotensin II type 1 receptor C allele + type 2 receptor A allele & \multicolumn{1}{c}{$(+)$} & \multicolumn{1}{c}{$(-)$} & \multicolumn{1}{c}{ Odds ratio } \\
\hline $64<$ AMI subjects $(n=78)$ & 13 & 65 & 3.40 (95\%CI 1.05-10.97) \\
& $(16.7 \%)$ & $(83.3 \%)$ & \\
$64 \geq$ AMI subjects $(n=72)$ & 4 & 68 & $p^{*=}=0.032$ \\
& $(5.6 \%)$ & $(94.4 \%)$ & \\
\hline
\end{tabular}

Table V. Multivariate Regression Analysis of Factors with Potential Effects on AMI

\begin{tabular}{lccc}
\hline \multicolumn{1}{c}{ Parameter } & B & SE(B) & $p$ \\
\hline Angiotensin II type 1 receptor C allele & 0.589 & 1.359 & 0.174 \\
Angiotensin II type 2 receptor A allele & 0.885 & 2.257 & 0.024 \\
Bradykinin B2 receptor C allele & 0.286 & 0.739 & 0.461 \\
Hypertension & 0.311 & 2.522 & 0.022 \\
Hypercholesterolemia & 0.791 & 0.468 & 0.043 \\
Diabetes mellitus & 0.276 & 0.133 & 0.018 \\
\hline
\end{tabular}

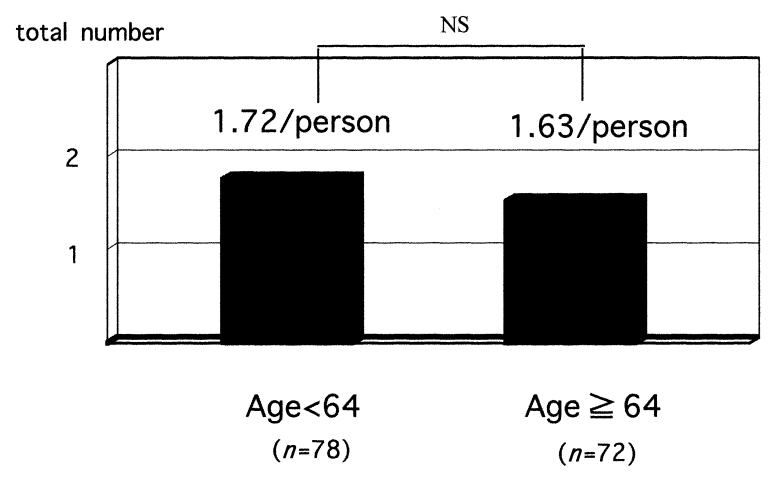

Figure 3. The total numbers of the conventional coronary risk factors in each AMI subject. Conventional coronary risk factors: hypercholesterolemia, diabetes mellitus and smoking. 
Table IV shows the combined ratios of the polymorphic alleles of the angiotensin II type 1 receptor C and type 2 receptor A. Since the combined ratios of the polymorphic alleles were significantly higher in the AMI subjects younger than 64 years old than in their older counterparts, we know that the younger AMI subjects have more polymorphic alleles.

Furthermore, for multivariate logistic regression analysis, subjects $(n=100)$ with hypertension or / and hypercholesterolemia or / and diabetus mellitus without AMI on routine visits to University Hospital were recruited in addition to the AMI subjects and controls. Multivariate logistic analysis (Table V) showed that only the angiotensin II type 2 receptor of these three genes was independently associated with the AMI, in contrast, the angiotensin II type 1 receptor and bradykinin B2 receptor were not independently associated with the AMI.

Figure 3 shows the total numbers of conventional coronary risk factors (i.e. hypertension, hypercholesterolemia, diabetus mellitus, smoking) in individual AMI subjects. There were a few more conventional coronary risk factors in the younger AMI subjects than in their older counterparts, but the differences in the total number of the conventional coronary risk factors between the groups were not significant.

\section{DISCUSSION}

In a large case-control study (ECTIM study), the ACE DD genotype was shown to be more frequent in patients with myocardial infarction than in control subjects. ${ }^{13)}$ Many other studies have confirmed the association of the D allele with an increased risk of myocardial infarction, ${ }^{34-36)}$ however, other studies did not detect any association between the $\mathrm{D}$ allele and risk of myocardial infarction. ${ }^{37-39)}$ Differences in population selection or interactions with other genetic polymorphisms of the renin-angiotensin system such as the angiotensin II type 1 receptor or type 2 receptor polymorphisms may account for these discrepancies.

The physiological role of the angiotensin II type 1 and type 2 receptors suggest that these genes might be candidate genes for myocardial infarction, possibly in interaction with the ACE I / D polymorphism.

In addition, angiotensin II receptor antagonists have recently been applied clinically for hypertension and congestive heart failure. The phamacological mechanism of angiotensin II receptor antagonists, namely, inhibition of the angiotensin II type 1 receptor and stimulation of the angiotensin II type 2 receptor, ${ }^{11,40)}$ poses interesting questions about the angiotensin II receptor polymorphisms. Angiotensin II type 1 and type 2 
receptors work controversially, ${ }^{11,40)}$ and the angiotensin II type 2 receptor polymorphism may relate to the important function of angiotensin IIangiotensin II type 2 receptor that leads to the development of common diseases. However, since few papers have described the angiotensin II type 2 receptor and its precise mechanism, further study will be needed to clarify the role of angiotensin II type 2 receptor.

In this study, we have found evidence for heterogeneity in genotype distributions. Since there were significant differences in genotypes and allelic frequencies in the angiotensin II type 1 receptor $\mathrm{A} / \mathrm{C}$ and angiotensin II type 2 receptor C/A polymorphisms between AMI and control subjects, we conjectured that the angiotensin II type 1 receptor 1166A/ $\mathrm{C}$ polymorphism might interact with the angiotensin II type 2 receptor 3123C / A polymorphism to promote the occurrence of AMI, and the copresence of additional polymorphisms compound this process. Furthermore, these tendencies were more significant in the younger group of AMI subjects.

The angiotensin II type 1 receptor $1166 \mathrm{~A} / \mathrm{C}$ polymorphism is located at the $5^{\prime}$ end of the $3^{\prime}$ untranslated region and does not alter potential messenger (m)RNA polyadenylation or destabilization signals. ${ }^{41}$ However, this polymorphism might be a marker in linkage disequilibrium with an unidentified functional variant that could affect the regulation of the gene in response to angiotensin II. Studies in a rat model that overexpresses the angiotensin II type 1 receptor in the myocardium suggest that the overexpression of the angiotensin II type 1 receptor under physiological conditions causes no change in cardiovascular structure, but pressure and volume overload in the same model led to hypertrophic growth. ${ }^{42}$ These results indicate that the angiotensin II type 1 receptor polymorphism in itself does not cause cardiovascular disorders, but they also suggest that this polymorphism can contribute to a process started by other factors. One of these factors could be the activity of plasma renin and its uptake by certain tissues, leading to local activation of the renin-angiotensin system. Generally speaking, it seems that in the development and progression of cardiovascular disease, genetic variation in the renin-angiotensin system becomes especially important when combined with other risk factors.

On the other hand, the present study suggests that there was no significant relation between the bradykinin $\mathrm{B} 2$ receptor polymorphism and AMI. While the bradykinin B2 receptor polymorphism may not influence the pathogenesis of AMI as strongly as angiotensin II type 1 and type 2 receptor polymorphisms, this polymorphism should not be overlooked, particularly in younger patients. This confirms that the bradykinin B2 
receptor polymorphism does not directly influence the occurrence of AMI, but we know that hypertension is an important coronary risk factor, and we already reported that the bradykinin $\mathrm{B} 2$ receptor $-58 \mathrm{~T} / \mathrm{C}$ polymorphism was associated with the occurrence of essential hypertension, ${ }^{24)}$ and the cardioprotective effect of ACE-inhibitor, an important effect for the inhibition of remodeling after acute myocardial infarction, is the inhibition of the degradation of bradykinin. ${ }^{43}$ Therefore, bradykinin B2 receptor polymorphism may influence the occurrence of AMI via hypertension, thereby influencing the pathogenesis of AMI indirectly.

Logistic analysis showed that the angiotensin II type 2 receptor of these three genes was independently associated with the AMI. In contrast, the angiotensin II type 1 receptor and bradykinin B2 receptor were not independently associated with the AMI, so we know that the influence of these gene polymorphisms to the pathogenesis of AMI was weaker than conventional coronary risk factors such as hypertension, hypercholesterolaemia, and diabetes mellitus. However, there has been no evidence until now that the polymorphisms of the angiotensin II type 1 receptor, type 2 receptor, and bradykinin $\mathrm{B} 2$ receptor are not related to hypertension, hypercholesterolaemia and diabetes mellitus, so it is difficult to decide whether the gene polymorphisms and conventional coronary risk factors are independent from each other. Therefore the influence of these gene polymorphisms on AMI may be multifactorial. Conventional coronary risk factors can directly or indirectly influence these polymorphisms, thereby altering the status of the renin-angiotensin system and the kallikreins-kinin system.

In conclusion, gene polymorphisms of the angiotensin II type 1 and type 2 receptors may promote the occurrence of AMI, and the co-presence of additional gene polymorphisms compound this process. These gene polymorphisms appear to be a new coronary risk factor, and they are probably associated with an increased responsiveness to angiotensin II. The occurrence of AMI might be reduced by management based on the genotypes.

\section{REFERENCES}

1. Alderman MH, Madhavan S, Ooi WL, Cohen H, Sealey JE, Laragh JH. Association of the renin-sodium profile with the risk of myocardial infarction in patients with hypertension. N Engl J Med 1991; 324: 1098-104.

2. Yusuf S, Pepine CJ, Garces C, et al. Effect of enalapril on myocardial infarction and unstable angina in patients with low ejection fractions. Lancet 1992; 340: 1173-8.

3. Davis GK, Roberts DH. Molecular genetics of the renin-angiotensin system: Implication for angiotensin II receptor blockade. Pharmacol Ther 1997; 75: 43-50. 
4. Koike G, Horiuchi M, Yamada T, Szpirer C, Jacob HJ, Dzau VJ. Human type 2 angiotensin II receptor gene: cloned, mapped to the $\mathrm{X}$ chromosome, and its mRNA is expressed in the human lung. Biochem Biophys Res Commun 1994; 203: 1842-50.

5. Koike G, Winer ES, Horiuchi M, et al. Cloning, characterization, and mapping of the rat type 2 angiotensin II receptor gene. Hypertension 1995; 26: 908-1002.

6. Grady EF, Sechi LA, Griffin CA, Schambelan M, Kalinyak JE: Expression of AT2 receptor in the developing rat fetus. J Clin Invest 1991; 88: 921-33.

7. Millan MA, Jacobowitz DM, Aguilera G, Catt KJ. Differential distribution of AT1 and AT2 angiotensin II receptor subtypes in the rat brain during development. Proc Natl Acad Sci USA 1991, 88: 11440-4.

8. Nio Y, Matsubara H, Murasawa S, Kanasaki M, Inada M. Regulation of gene transcription of angiotensin II receptor subtypes in myocardial infarction. J Clin Invest 1995; 95: 46-54.

9. Lopez J, Lorell BH, Ingelfinger JR, et al. Distribution and function of cardiac angiotensin AT1-and AT2-receptor subtypes in hypertrophied rat heart. Am J Physiol 1994; 36: H844-52.

10. Nakajima M, Hutchinson HG, Fujinaga M, et al. The angiotensin II type 2 (AT2) receptor antagonizes the growth effects of the AT1 receptor: gain-of-function study using gene transfer. Proc Natl Acad Sci USA 1995; 92: 10663-7.

11. Jalowy A, Schulz R, Dorge H, Behrends M, Heusch G. Infarct size reduction by AT1-receptor blockade through a signal cascade of AT2- receptor activation, bradykinin and prostaglandins in pigs. J Am Coll Cardiol 1998; 32: 1787-96.

12. Kuizinga MC, Smits JFM, Arends JW, Daemen MJAP. AT2-receptor blockade reduces cardiac interstitial cell DNA synthesis and cardiac function after rat myocardial infarction. J Mol Cell Cardial 1998; 30: 425-34.

13. Cambien F, Poirier O, Lederf L, et al. Deletion polymorphism in the gene for angiotensin-converting enzyme is a potent risk factor for myocardial infarction. Nature 1992; 359: 641-4.

14. Tiret L, Bonnardeaux A, Poirier O, et al. Synergistic effects of angiotensin-converting enzyme and angiotensinII type 1 receptor gene polymorphisms on risk of myocardial infarction. Lancet 1994; 344: 910-3.

15. Hall JM. Bradykinin receptors. Gen Pharmac 1997; 28: 1-6.

16. Dray A, Perkins M. Bradykinin and inflammatory pain. Trends Neurosci 1993; 16: 99-104.

17. Bhoola KD, Figueroa CD, Worthy K. Bioregulation of kinins, kallikreins, kininogens, and kininases. Pharmacol Rev 1992; 44: 1-80.

18. Farmer SG, Burch RM. Biochemical and molecular pharmacology of kinin receptors. Ann Rev Pharmacol Toxicol 1992; 32: 511-36.

19. Seguin L, Widdowson PS, Giesen-Crouse E. Existence of three subtypes of bradykinin B2 receptors in guinea pig. J Neurochem 1992; 59: 2125-33.

20. Hess JF, Borkowski JA, Young GS, Strader CD, Ransom RW. Cloning and pharmacological characterization of a human bradykinin (BK-2) receptor. Biochem Biophys Res Comm 1992; 184: 260-8.

21. Braun A, Kammerer S, Bohme E, Muller B, Roscher AA. Identification of polymorphic sites of the human bradykinin $\beta 2$ receptor gene. Biochem Biophys Res Comm 1995; 211: 234-40.

22. Kammerer S, Braun A, Arnold N, Roscher AA. The human bradykinin $\beta 2$ receptor gene: full length cDNA, genomic organization and identification of the regulatory region. Biochem Biophys Res Comm 1995; 211: 226-33.

23. Braun A, Kammerer S, Maier E, Bohme E, Roscher AA. Polymorphism in the gene for the human $\beta 2$ - bradykinin receptor. New tools assessing a genetic risk for bradykinin-associated diseases. Immunopharmacology 1996; 33: 32-5.

24. Mukae S, Aoki S, Itoh S, et al. Promoter polymorphism of the B2 bradykinin receptor gene is associated with essential hypertension. J Circ J 1999; 63: 759-62.

25. Tiret L, Kee F, Poirier O, et al. Deletion polymorphism in angiotensin-converting enzyme gene associated with parental history of myocardial infarction. Lancet 1993; 341: 991-2.

26. Jeunemaitre X, Ledru F, Battaglia S, et al. Genetic polymorphisms of the renin-angiotensin system and angiographic extent and severity of coronary artery disease: the CORGENE study. Human Genet 1997; 99: 66-73.

27. Poirier O, Georges JL, Ricard S, et al. New polymorphisms of the angiotensin II type 1 receptor gene and their association with myocardial infarction and blood pressure: the ECTIM study. J Hypertension 1998; 16: 1443-7.

28. Yoneya K, Okamoto H, Machida M, et al. Angiotensin-converting enzyme gene polymorphism in Japanese patients with hypertrophic cardiomyopathy. Am Heart J 1995; 130: 1089-93. 
29. Zhao Y, Higashimori K, Higaki J. Significance of the deletion polymorphism of the angiotensin-converting enzyme gene as a risk factor for myocardial infarction in Japanese. Hypertens Res 1994; 17: 55-7.

30. Takami S, Katsuya T, Rakugi H, et al. Angiotensin II type 1 receptor gene polymorphism is associated with increase of left ventricular mass but not with hypertension. Am J Hypertens 1998; 11: 316-21.

31. World Health Organization diabetes mellitus: report of a WHO study group. WHO Teah Rep Ser 1985; 727: 9.

32. Doria A, Warram JH, Krolewski AS. Dde I polymorphism in the AT1R gene. Hum Mol Genet 1994; 3: 1444.

33. Katsuya T, Horiuchi M, Minami S. Genomic organization and polymorphism of human angiotensin II type 2 receptor: no evidence for its gene mutation in two families of human premature ovarian failure syndrome. Mol Cell Endocrinol 1997; 127: 221-8.

34. Ruiz J, Blanche H, Cohen $\mathrm{N}$, et al. Insertion / deletion polymorphism of the angiotensin-converting enzyme gene is strongly associated with coronary heart disease in non-insulin-dependent diabetes mellitus. Proc Natl Acad Sci USA 1994, 91: 3662-5.

35. Mattu RK, Needham EW, Galton DJ, Frangos E, Clark AJ, Caulfield M. A DNA variant at the angiotensinconverting enzyme gene locus associates with coronary artery disease in the Caerphilly Heart Study. Circulation 1995; 91: 270-4.

36. Ludwig E, Corneli PS, Anderson JL, Marshall HW, Lalouel JM, Ward RH. Angiotensin-converting enzyme gene polymorphism is associated with myocardial infarction but not with development of coronary stenosis. Circulation 1995; 91: 2120-4.

37. Friedl W, Krempler F, Paulweber B, Pichler M, Sandhofer F. A deletion polymorphism in the angiotensin converting enzyme gene is not associated with coronary heart disease in an Austrian population. Atherosclerosis 1995; 112: 137-43.

38. Lindpaintner K, Pfeffer MA, Kreutz R, et al. A prospective evaluation of an angiotensin-converting-enzyme gene polymorphism and the risk of ischemic heart disease. N Engl J Med 1995; 332: 706-11.

39. Katsuya T, Koike G, Yee TW, et al. Association of angiotensinogen gene T235 variant with increased risk of coronary heart disease. Lancet 1995; 345: 1600-3.

40. Tsutsumi Y, Matsubara H, Ohkubo N, et al. Angiotensin II type 2 receptor is upregulated in human heart with interstitial fibrosis, and cardiac fibroblasts are the major cell type for its expression. Circ Res 1998; 83: 103546.

41. Bonnardeaux A, Davies E, Jeunemaitre X, et al. Angiotensin II type 1 receptor gene polymorphisms in human essential hypertension. Hypertension 1994; 24: 63-9.

42. 42.van Geel PP, Pinto YM, Buikema H, van Gilst WH. Is the A1166C polymorphism of the angiotensin II type 1 receptor involved in cardiovascular disease? Eur Heart J 1998; 19: G13-7.

43. Linz W, Wiemer G, Gohlke P, Unger T, Scholkens BA. Contribution of kinins to the cardiovascular actions of angiotensin -converting enzyme inhibitors. Pharmacol Rev 1995; 47: 25-49. 
